\title{
NATURAL REVELATION AND THE PURPOSE OF THE LAW IN ROMANS
}

\author{
Mark A. Seifrid
}

In Romans 1-2, Paul argues the justice of divine wrath upon idolatry and upon the one who judges another. Jews and Gentiles enter his argument only as individuals, not as ethnic groups. Only in Romans 3 does Paul bring the charge that all human beings are idolaters. In establishing the justice of God's wrath, Paul claims that even Gentiles without the Law fully possess the knowledge of God's will, through their participation in the created order. Consequently, the advantage of the Jew lies in the possession of the oracles of God, which make known divine judgement and salvation. Correspondingly, a distinctive function of the Law emerges in Romans 3:19-20, namely, the outward and objective establishing of human guilt. It is this aspect of the Law which sets it apart from natural law, and which makes it a witness to the righteousness of God given in Christ.

It is impossible to treat Paul's understanding of the law of Moses rightly apart from some discussion of 'natural revelation' in Paul's letter to Rome. The two themes are linked in Romans 2:12-16 in such a way that the interpretation of one inevitably affects the interpretation of the other. Our aim here is to follow the basic lines of Paul's argument in Romans 1-3, and in so doing stake out the relation between the two themes, thus highlighting the distinctive function of the law of Moses according to Paul. ${ }^{1}$

As is well-known, Paul's exposition in Romans of the gospel which he proclaimed among the gentiles calls forth from him in Romans 1:18-3:20 a description of the condition of the gentiles among whom he proclaimed that gospel. Equally obvious is the remarkably high value which Paul accords natural revelation at the outset of his argument. Indeed, his claim in Romans 1:20, 'that which is known of God is manifest among them', is so remarkably bold that interpreters often feel

${ }^{1}$ Much of the following argument shall appear in a forthcoming work on Paul's theology of justification with which I am presently engaged. 
compelled to add their own qualification to the text. Paul must here speak of a 'rudimentary knowledge' of God to which special revelation is added as a supplement. ${ }^{2}$ We may ask, however, if such a reduction of Paul's language accords with his argument. Although it is generally assumed that Paul here lays a charge against all gentiles, or perhaps the whole world, Jew and Gentile alike, his discussion has not yet progressed so far. We cannot legitimately read Romans 3 back into Romans 1 . Paul does not speak of the wrath of God revealed against the 'unrighteousness of all human beings' in Romans 1:18, but of the wrath of God revealed against 'all ungodliness and unrighteousness of those who suppress the truth in unrighteousness'. In Romans 1:18-32 Paul attacks all idolatry, but has not yet brought his charge that all are idolaters. ${ }^{3}$

We may freely admit that in Romans 1:18-32 Paul primarily has in view Gentile society seen from a Jewish and biblical perspective. The orientation of his argument is clear not only from parallel descriptions of Gentile idolatry which appear in early Jewish literature (as, for example, in Wis. Sol. 13-14), but also from the attack upon 'wisdom so-called' which lies at the centre of his polemic: those who professed to be wise became fools (1:22). Here Paul exposes the pretensions of Hellenistic society, just as he subsequently calls into question Jewish presumption of privilege in the possession of the law. Nevertheless, his accusation is not directed against gentiles as such, but against those who worship idols. His argument is similar to the address to the 'Jew so-called' in Romans 2:17-29, where a charge is laid against the one whose transgression of the law renders his boast in the law a false one. Furthermore, Paul's interrogation of a Jewish dialogue partner in the same passage shows that it was quite conceivable to him that some of

\footnotetext{
2So, for example, J. Stott, Romans: God's Good News for the World (Downers Grove: Inter Varsity, 1994) 74; D.J. Moo, The Epistle to the Romans (NICNT; Grand Rapids: Eerdmans, 1996) 106-107. Cf. E. Käsemann, Commentary on Romans (Grand Rapids: Eerdmans, 1980) 41-42; U. Wilckens, Der Brief an die Römer (2nd ed.; EKK VI/1; Neukirchen: Neukirchen-Vluyn, 1987) 105107.

3See J.-N. Aletti, 'Romains 2: Sa cohérence et sa fonction', Biblica 77 (1996) 170-74.
} 
his Jewish contemporaries could fall into the idolatry which characterised Israel's past (2:22). 4 They too are included within the scope of the charge in Romans 1. Likewise, Paul's admonition of 'the strong' in Romans 14 indicates that he was well aware that gentiles were capable of passing judgement on their neighbours (14:1-13). Not merely the Jew, but also the moralising Gentile is subject to the condemnation which he describes in Romans 2:1-11. Although Paul's description of the wrath of God is centred upon Hellenistic society in Romans 1, he intentionally does not limit the range of its effects to the Gentile world.

In this regard, we should note that Paul does not name those of whom he speaks as gentiles, and does not reintroduce the categories of 'Jew and Greek' until Romans 2:9-10. This delay must be regarded as intentional, since when Paul shifts away from the topic of idolatry at Romans 2:1, he likewise refrains from describing his rhetorical addressee as a Jew, but simply speaks to anyone who judges another ( $\pi \hat{\alpha} \varsigma$ ó $\kappa p i v \omega v)$. The parallelism is obvious: just as in Romans 2:1-11 Paul underscores the justice of divine judgement upon anyone who assumes the role of judge, in Romans 1:18-32 he treats the righteousness of God's wrath upon all who worship idols. He omits the usual ethnic stereotypes precisely because they are for him theologically irrelevant, and indeed, misleading. Particularly in Romans 2:1-3:8, Paul isolates the individual and places each one in foro Dei. Whether Jew or Greek, each one shall receive just recompense for his or her deeds at the coming day of judgement (2:8-11). God shall judge the secrets of every heart through Christ Jesus (2:16). It is a singular partner in dialogue whom Paul addresses in Romans 2:17-29, and a single obedient Gentile whom he sets over against the 'Jew so-called'. 5 His argument takes a form similar to that of the prophet

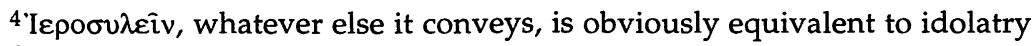
for Paul.

5Paul's obvious stripping away of social identity in favour of individual responsibility before God is the polar opposite to modern 'individualism' of which those in modern western societies are so often guilty. On this topic, see R. Bellah, et al., Habits of the Heart: Individualism and Commitment in American Life (New York: Harper \& Row, 1985) esp. 219-49.
} 
Nathan's confrontation of David. Paul calls his readers to recognise the justice of the divine wrath against all idolatry, judgmentalism, and pretence, and only when this agreement is secured does he introduces the prophetic charge, 'Every human being is a liar' (3:4). ${ }^{6}$ The course of his argument up to this point is preparation. Romans 1:18-32 represents the first phase of that preparation, in which he seeks to demonstrate the justice of God's wrath against all idolatry.

The recognition of the specificity of Paul's aim in Romans 1:18-32 allows for a much more integrated reading of Romans 1 and 2. Under the assumption that Paul asserts in Romans 1 that gentiles are under divine wrath, his further argument in Romans 2:12-16 that gentiles are liable to judgement on the basis of the 'work of the law' written in their hearts appears superfluous. The complementarity and coherence of the two passages becomes apparent once we recognise the shift in topic from the justice of God's wrath upon idolatry to the justice of his judgement upon those without the law. In Romans 1 Paul speaks of God's giving over idolaters to the violation of nature, the abandonment of natural sexual relations ( $\dot{\eta} \phi v \sigma \iota \kappa \dot{\eta} \chi \rho \hat{\eta} \sigma \iota \varsigma)$ and the pursuit of that which is unnatural ( $\pi \alpha \rho \dot{\alpha} \phi v \dot{\sigma} v, 1: 26-27)$. In Romans 2:14 he speaks of gentiles who at times 'do the things of the law by nature ( $\phi v \delta \varepsilon \imath)^{\prime}$. Consequently, his two uses of 'natural revelation' do not stand in conflict with one another, and in fact may be seen to interlock. 7

Above all else, the recognition that Romans 1:18-32 has to do with God's wrath upon idolatry allows proper weight to be given to Paul's obvious emphasis upon the injustice of idolatry and the equity of the divine retribution. It is worth noting that he immediately defines 'ungodliness' as

6In confirmation of this reading, we may note that when Paul in 3:9 describes the nature of his discourse up to that point, he says, 'we have already charged that Jews and Greeks are under sin': charged, not argued or demonstrated. Wilckens (Römer, 116) likens Paul's argument at 2:1 to 2 Sa. 12, although no charge properly appears until later.

${ }^{7}$ Consequently, H. Räisänen's claim (Paul and the Law [Philadelphia: Fortress, 1986] 101-109) that Paul's argument in Romans 1-2 is 'strained and artificial' lacks any force. 
'unrighteousness', and names 'the unrighteousness of human beings' as that which calls forth the wrath of God (1:18). He sets forth a series of striking paradoxes in order to underscore precisely this point. The 'unseen things of God' are clearly seen through what has been made, so that idolaters are without excuse (1:20). Although such persons profess to be wise, they have become fools (1:22). Idolatry is nothing other than the exchange of the glory of the incorruptible God for the image of the corruptible creature' (1:23). In the same manner, Paul describes the divine surrender of idolaters to their desires in an emphatic, threefold ius talionis: (1) God has delivered over those who worship the image of the corruptible human to the dishonouring of their bodies (1:24-25); (2) God has delivered over those who worship the creature rather than the creator to corrupting the created order present in their own persons (1:2627); and (3) God has delivered over to a reprobate mind

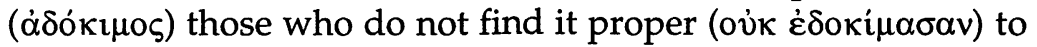
remember God (1:28-29). Interpreters universally have noticed this aspect of Romans 1 . Yet we fail to do it justice unless we recognise that it is the central feature of Paul's argument. Paul aims here at showing that those who commit idolatry are without excuse ( $\dot{\alpha} v \alpha \pi \circ \lambda \circ \gamma \eta \dot{\eta} \tau \varsigma_{1}, 1: 20$ ), just as he argues the same in Romans 2:1-11 concerning the one who judges the other

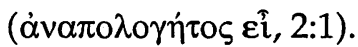

Consequently, Paul's reference to natural revelation in Romans 1:19-20 must be understood within the context of idolatry. Paul does not in the first instance inform us about some residual capacity within the fallen human being, but charges that idolatry entails the unjustified suppression of God's self-manifestation through the created order. His language makes it clear that he has in view a knowledge of God as creator which is full and sufficient for the creature to

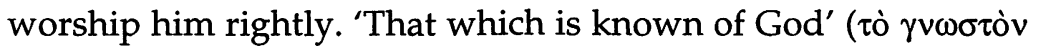

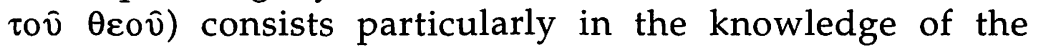
distinction between the visible creation and God's 'unseen being', his eternal power and deity which distinguishes him from that which he has made and sustains (1:20). It is incumbent upon the human creature to glorify and give thanks to this one eternal, beneficent and unseen creator. That is 
precisely what the idolater refuses to do. The only natural theology of which Paul speaks here is that which appears in the form of idolatry. His gospel does not supplement this theology, but destroys it, and establishes for the first time the proper relation between creature and creator which natural revelation itself demands. 8

Paul's further argument reveals that he regards the created order as imparting not only a knowledge of God the creator, but a knowledge of his will. If we stand at the transitional point between Romans 1 and Romans 2 we may profitably glance both forward and backward. Although idolaters 'know the righteous ordinance of God' that those who engage in the vices which Paul names are 'worthy of death', they not only engage in them but approve those who do likewise (1:32). There is no good reason why this awareness of God's will should be attributed to the presence of synagogues in the Hellenistic world, especially in the light of Paul's subsequent claim that 'the work of the law' is written in the heart of gentiles (2:15). The fallen human being is not only an observer of the created order, but a participant in it: gentiles sometimes 'by nature' perform the 'things of the law' (2:14). As God's creation, the human being remains a moral being, and cannot become amoral, only immoral. Seen in this light, Romans 1:32 reveals the considerable dimensions of natural revelation in Paul's understanding. The worship and thanksgiving which the human creature owes the creator according to 1:21 entails much more than lip service. It includes that 'righteous decree of God' named here, which in negative manner encompasses the whole of our proper service of God with 'body' and life. Correspondingly, the judgement of God

${ }^{8}$ Since Paul later charges all humanity with idolatry, debates concerning the propriety of a 'natural theology' cannot be avoided. Here I wish to make clear that I certainly do not embrace K. Barth's ontological rejection of natural theology. E. Brunner had the better part of the famous debate. I would merely make a distinction between the ongoing revelation of the creator in the natural order ('natural revelation') and its reception by fallen humanity in the form of idolatry (which is the only form 'natural theology' can take). There is an Anknüpfungspunkt, where the gospel contacts the fallen human being, yet it is always an Angriffspunkt, a point of attack. 
described in Romans 1, the three-fold 'delivering up' of idolaters, anticipates the mercies of God in Romans 12, which liberate us from idolatry and effect worship of the one true God in and among us.

With this background, we may properly fix our attention on Romans 2:12-16, in which the two themes of the law and natural revelation meet. Here again we find cause for drawing a distinction which is generally overlooked. Interpreters usually regard Paul as making a statement about gentiles, and argue as to whether believing or unbelieving gentiles are in view. Of course, Paul does speak about gentiles in this passage, but his interest in them does not rest on their ethnicity as such, nor on their status with respect to the gospel, but on their anomia. He signals this concern not only his description of them as 'those without the law' (2:14), but also in his introduction to this section in which he asserts that those who 'sinned without the law shall perish without the law' (2:12). His immediately preceding depiction of 'the righteous judgement of God' concludes with a straightforward denial that God will make any distinction between Jew and Greek: there is no partiality with God (2:9-11). Now Paul provides a warrant for that claim, a warrant which is highly instructive, since it reveals that in Paul's view a Jew might have pointed to Israel's possession of the law as a significant qualification of the divine impartiality which Paul has just claimed (2:11). Paul's aim consequently is to dispel the notion that lack of knowledge of the law might represent a disadvantage at the day of judgement. This becomes clear in his subsequent characterisation of his imaginary Jewish dialogue partner, who supposes that because he discerns that which is morally excellent from the law, he may serve as 'a guide to the blind, a light to those in darkness, an instructor of the foolish, a teacher of infants' (2:18-20). The fault here lies not in the exclusion of gentiles from salvation, nor in the assumption of some 'national privilege' in the narrow sense, but in the presumption that with mere knowledge of the law the Jew was privileged and had something to offer the Gentile. Paul exposes the fallacy of this thinking from two different angles. In Romans 2:17-29 he makes clear that mere knowledge of God's will has not secured Jewish 
obedience, so that there is no advantage to be found in the knowledge of the divine demands. In our text, Romans 2:12-16, Paul makes clear that Gentile disobedience to God is not due to a lack of knowledge of his will. While a Jew might have supposed that a Gentile had something to gain in becoming a 'hearer of the law' (2:13), Paul insists that in this regard the Jew had nothing to offer. Divine impartiality is not in any way diminished by the anomia of gentiles. ${ }^{9}$

Paul's argument here turns upon the 'full' understanding of natural revelation which we have described above. Those who do not have Torah function as Torah for

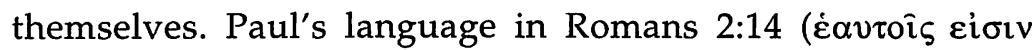
vómo૬) must surely understood in this way. He does not argue that gentiles are 'a law unto themselves', but that their performance of the requirements of the law fulfils the role of the law in a crucial way. Although they lack the external address of the law, the created order of which they are a part ( $\phi v i \sigma \varsigma)$ supplies an equivalent internal witness. Those who sin without the law (ávó $\mu \omega \varsigma$ ) shall perish at the final judgement. This shall take place justly and without diminishing divine impartiality, because the intended effect of the law ( $\tau$ ò épyov vó $\mu \mathrm{ov}$ ) has been written upon their hearts. Here we must underscore that Paul does not speak of the law being written upon their heart, but of the work of the law written in their hearts. We can hardly think that Paul speaks simply and particularly of believing gentiles here, since he supposes that some of them will be condemned at the day of judgement (2:16). ${ }^{10}$ Moreover, his immediate concern in this context is to explain the just condemnation of those without the law (2:12). He uses the language of 'inscription upon the heart' because he sees in 'nature' a parallel to the law's role in addressing the human being with the demands of God, a function which he elsewhere describes as $\gamma \rho \alpha \dot{\mu} \mu \alpha$, 'letter' (including the conclusion

\footnotetext{
${ }^{9}$ See the similar discussion of this passage in J. Bassler, Divine Impartiality: Paul and a Theological Axiom (SBLDS 59; Chico: Scholars Press, 1982) 139-49. ${ }^{10}$ N.T. Wright attempts to support this interpretation by reading the passage backwards. See his 'The Law in Romans 2', in J.D.G. Dunn (ed.), Paul and the Mosaic Law (WUNT 89; Tübingen: Mohr, 1996) 131-50.
} 
of this chapter, 2:27, 29). ${ }^{11}$ In short, Paul claims that occasional obedience to the demands of the law by gentiles provides evidence that all that the law might accomplish in imparting the knowledge of God's will has been written in human hearts already by the hand of the creator. As in Romans 1, Paul's statement concerning 'the work of the law' is unqualified. As far as the final judgement is concerned, the work of God the creator within the fallen human being is equal to the manifestation of his will in the law of Moses.

This 'work of the law' is not to be identified with the witness of the conscience of which Paul speaks in Romans 2:16. It is rather the object and content of that witness. 12 As in Romans 8:15 and 9:1, and as in secular Greek, the compound form $\sigma v \mu \mu \alpha \rho \tau v \rho \varepsilon \dot{c} \omega$ should be given its full weight. ${ }^{13}$ The conscience serves as a co-witness alongside the gentiles' obedient deeds to this 'work of the law written in the heart'. Furthermore, Paul is not concerned here to describe the function of the conscience within the fallen order. When he expands and explains this 'witness of the conscience', he speaks only of the day of judgement at which the thoughts of gentiles shall accuse or defend them (2:15-16).14 At that time the

${ }^{11} \mathrm{His}$ choice of the word 'heart' hardly requires explanation: it is Paul's usual term for describing the seat of knowledge and affections, reflective of biblical usage, and shaped by its holistic perspective on the human being.

${ }^{12}$ Nor are 'the gentiles' the object of the witness of the conscience. In that case we would find in the dative pronoun aviois rather than the genitive $\alpha \dot{\tau} \tau \bar{\omega} v$ following the verb (2:15).

${ }^{13}$ Here I am to a certain extent following H.-J. Eckstein, Der Begriff Syndeidesis bei Paulus (WUNT 2.10; Tübingen: Mohr, 1983) 159-61.

${ }^{14}$ It therefore seems clear that Paul indicates that some gentiles will be acquitted at the judgement seat of God: their thoughts accuse or even defend them. In view of his subsequent charge that 'all human beings are liars' (3:4), Paul only can have in mind the justification of believing gentiles at the judgement seat of God. His introduction of the idea that some 'lawless' gentiles might be acquitted at the final judgement was undoubtedly intentionally provocative to Jewish sensibilities, and anticipates his immediately following argument in which he argues that the uncircumcised person who keeps the law shall judge the circumcised transgressor (2:17-29). One of the major failings of D. Campbell's reading of Romans 2 ('A Rhetorical Suggestion Concerning Romans 2', Society of Biblical Literature 1995 Seminar Papers [Atlanta: Scholars Press, 1995] 140- 
conscience along with the deeds of gentiles will serve as a witness to the work of God the creator within each of their hearts. That work, as we have seen, is the impartation of the knowledge of his will as contained in the law.

Paul does not imagine that the Gentile world generally embraces and accepts this knowledge. Quite the contrary, his statements in Romans 1:28-32 and his need to argue the matter suggest just the opposite, that the creator's imprint of his will upon the human creature is largely suppressed, just as the knowledge of God the creator has been perverted by idolatry. Nevertheless, it is fair to say that Paul does not argue that each one is responsible for the light which he or she enjoys, he rather argues that Jew and Gentile alike have enjoyed equal light.

Obviously in speaking in this way Paul views the law from a particular angle, freely omitting the aspects of the law which particularly apply to Israel. These he takes up in the most remarkable way in his discussion of circumcision in Romans 2:17-29. For Paul, circumcision marks the one who is a Jew, but only under the condition of a great transposition. It is not an outward and visible sign coram hominis, but an inward sign coram Deo. In this interpretation, Paul has his precedents in the Deuteronomic promise of the circumcision of the heart and the Jeremianic pronouncement upon the house of Israel. 15 His treatment of the topic of circumcision here need not be regarded as standing at odds with his subsequent claim that Abraham's circumcision was a sign of his uncircumcised faith, and the deeper biblical-theological unity of his two treatments of circumcision deserves further discussion elsewhere. It suffices for us here to note that broadly speaking Paul treats the

67 ) is that he fails to understand that Paul regards the gospel as effecting true obedience. Consequently, Paul's reference to believing gentiles is not a mere rhetorical flourish, intended to show the absurdity of a judgement according to works. Quite the opposite: Paul directs the attention of his readers to the fulfilment of the law in the gospel. In the immediate context, the distinction between believing and unbelieving gentiles is immaterial to Paul's main point. Whether believing or unbelieving, gentiles are óvó $\mu \omega s_{\text {, }}$ i.e., without the law of Moses. Against Bassler (Divine Impartiality, 142), it is not at all difficult to suppose that Paul regarded believing gentiles in this way (e.g., 7:4-6).

${ }^{15}$ See Dt. 10:16; 30:6; Je. 4:4; 9:25-26. 
matters of the law pertaining particularly to Israel under the rubric of promise, not law, and that in Romans 2:12-16, Paul gives primacy to the universal demands of the law. It is one of his burdens to cause his readers to see the demands of the law in the context of creation, rather than merely in relation to Israel.

Consequently, 'the advantage of the Jew' for Paul lies not in the knowledge of God's will mediated by the law, but in the $\lambda$ ó $\gamma 1 \alpha$, the 'oracles' of God with which Israel has been entrusted (3:1-2). ${ }^{16}$ Although this section of the letter, which extends through Romans 3:18 is of crucial importance to discerning Paul's conception of justification, we can give it only cursory attention here. It suffices to say that we miss the point of Paul's unusual appeal to oracular speech, if we reduce the sense of $\lambda$ ó $\gamma 1 \alpha$ to that of 'promises'. The function of an oracle, as Romans 11:4 shows, is to reveal divine knowledge which is otherwise inaccessible to the human being. As Paul's following citations of Psalms 116 and 51, and the chain-citation of Romans 3:10-18 show, in speaking of the 'oracles of God' he has in view not merely divine promises to Israel, but also words of judgement. Moreover, as becomes clear in Paul's discussion of Israel in Romans 9-11, God's ways with his people, whether Jew or Gentile, are beyond human understanding, and necessarily so. Salvation always comes in and through divine judgement. God calls those who are not his people to be his people (9:2526). Through bringing destruction and exile God saves a remnant by his grace (9:29). He hardens Israel and treats them as enemies in order to save them (11:25-26). God has shut up all in disobedience, so that he might have mercy upon all (11:32). From this perspective, the breadth of Paul's reference in Romans 3:2 to the $\lambda$ ó $\gamma \iota \alpha$ of God is understandable. The $\lambda$ ó $\gamma \iota \alpha$ make known God's untraceable ways in judging and saving and as such demand faith and anticipate the gospel (3:3).

The final reference to the law with which we shall concern ourselves here appears in Romans 3:19-20. It is rather

\footnotetext{
${ }^{16}$ Another major fault of Campbell's reading of Rom. 2-3 ('Rhetorical Suggestion', 148-49) is his failure to see that divine impartiality in a judgement according to works does not at all nullify Israel's election according to Paul.
} 
difficult to discern the relation of this brief statement to what precedes. One's first impulse is to suppose that it summarises the immediately preceding chain-citation. It is more likely, however, that it recalls Paul's earlier treatment of the law in Romans 2:17-29, forming something of an inclusio which rounds off a distinct section of the letter (2:17-3:20). The term vó $\mu$ os reappears here for the first time since the end of Romans 2. Moreover Paul here introduces new categories which anticipate his subsequent argument in Romans 3:27-7:25, speaking for the first time in the letter of the 'works of the law' which cannot justify, and of the 'knowledge of $\sin ^{\prime}$ which comes through the law. In these verses we have to do with a dense theological confession ('we know...') which both prepares for Paul's exposition of the justifying work of the cross in Romans 3:21-26 and lays the groundwork for his further explication of the function of the law.

We may adequately address our concerns in this passage by giving our attention to the translation of the text:

We know that whatever the law says, it speaks to those in the law, in order that every mouth might be closed and all the world might be held guilty before God. Because by the works of the law no flesh shall be justified before him, for through the law comes the knowledge of sinning (3:19-20). ${ }^{17}$

I have rendered $\dot{\tau} \pi$ ó $\delta$ ко $\varsigma$ here as 'guilt' before God rather than as the usual 'accountability' before God ( $c f$. NIV, NRSV). This reading is to be preferred for several reasons:

(1) The sense of 'guilt' is normally attached to this word, particularly in secular Greek. 18

(2) The preceding chain-citation obviously does not have to do with accountability, but with guilt. Since it is fairly clear that Paul continues the thought of this citation when he speaks of 'whatever the law says', it is

\footnotetext{
${ }^{17}$ On this reading of the text, see also O. Hofius, 'Das Gesetz des Mose und das Gesetz Christi', in his Paulusstudien (Tübingen: Mohr, 1989) 57.

18BAAR, s.v. 'vं $\pi \delta 1 \kappa \varsigma^{\prime}$. The word appears clearly with this sense in both Philo and Josephus, e.g Philo, Spec. Leg. 2.249; Josephus, Vita 74.
} 
probable that he speaks of condemnation, not merely accountability.

(3) Paul has just argued that the gentiles are fully accountable without the law (2:12-16). It hardly makes sense for him to reverse his position and imply that the law is necessary to the accountability of all human beings.

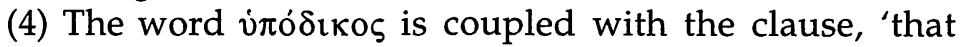
every mouth might be closed', an expression which is used in the Hebrew Bible to describe the silencing of the wicked and guilty. ${ }^{19}$

Secondly, the expression, 'the knowledge of $\sin ^{\prime}$ most likely signifies the experience of sinning, not an awareness of guilt. Again several reasons may be adduced in favour of this interpretation:

(1) The phrase appears in an unconditioned theological assertion. Paul does not describe what the law can do or might do if the human being properly uses it. He simply claims that 'the knowledge of sin comes through the law'. The aim of Paul's argument begun at Romans 1:18 has been to persuade readers who know the law that all humanity stands guilty before God. If the law of itself sufficiently brings awareness of guilt, why does Paul bother to argue this matter?

(2) The phrase is naturally taken as an anticipation of Paul's description of the human encounter with sin in Romans 7:7-13, where Paul clearly speaks of the knowledge of sin as the coming to know the reality of sinning:

What therefore shall we say? Is the law sin? May it never be! Nevertheless, I would not have known sin except through the law, for I would not have known coveting unless the law had said, 'You shall not covet'. And sin, taking opportunity worked in me all coveting through the commandment. (7:7-8a).

Nothing in this statement or its context suggest that Paul's encounter with the prohibition against coveting

19Ps. 63:11; Ps. 107:42; Jb. 5:16. 
brought him an awareness of the sentence of death upon him, i.e. an awareness of guilt in the proper sense. His point here is that indwelling sin objectively manifested itself by working his death through the good law of God.

(3) Nowhere in Romans, or for that matter elsewhere in Paul's letters, does Paul suggest that by effecting human transgression the law necessarily produces a sense of guilt within the human being. Paul rather speaks about an objective state of affairs in the world which the law establishes. Romans 3:19-20, with its obvious forensic orientation, fits into this pattern. Paul will necessarily return to this topic in Romans 7, explaining how it is that the good law of God works such negative results. Here however, he is content to leave the matter stand.

A second function of the law therefore emerges in Romans 3:19-20, different from the work which is paralleled in natural revelation. Unlike the will of the creator written in the heart, which shall be fully manifest only when God judges the secrets of human hearts at the day of judgement, the commandment stands presently over and against 'those in the law' and accuses them. The demands of the law transcend natural revelation, not by supplementing any particular knowledge of God's will, nor by in themselves bringing a sense of guilt, but by openly displaying the condition of the human being. The law establishes God's just charge against humanity in the public square, whether humanity acknowledges it or not. It is this function of the law which comes to expression in Paul's two subsequent articulations of the purpose of the law in Romans: 'the law works wrath' (4:15); 'the commandment entered in order that the transgression might multiply' (5:20). The law replicates the Adamic transgression against an extrinsic demand of God (5:14) in each one who encounters it. That is the main thrust of Romans 7, in which the good law meets with the human being in bondage to sin. For Paul the outward and objective work of the law, not its inward and subjective effect upon the human being is decisive. It was into the world thus subjected to the power of sin and death that the 
son of God was sent as an offering for $\sin (\pi \varepsilon \rho i$ d $\mu \alpha \rho \tau i \alpha \varsigma, 8: 3$ ) and in which he performed the decisive act of obedience on the cross (5:19). This is the decisive and distinct work of the law of Moses according to Paul.

Obviously the law is not God's final word to humanity. It has its counterpart in the 'righteousness of God' which apart from the law has been revealed in the cross and resurrection of Christ. This distinction of roles, which Paul underscores in Romans 3:21 is obviously essential to him. In the purpose of God, the law brings the open and public sentence of death in order that the gospel might have its proper effect. The first work is essential to the second: only where God has condemned and put to death does he vindicate and raise to life. Of course the law itself witnesses to the 'righteousness of God' which follows it (3:21). This witness very likely rests in the primary and distinctive function of the law of Moses which we have seen. The very offer of life which the law holds forth in effecting the misery of death (7:10), already intimates the gospel of Christ in whom the $\tau \varepsilon \dot{\lambda} \lambda \varsigma_{\zeta}$ of the law is a present reality. 